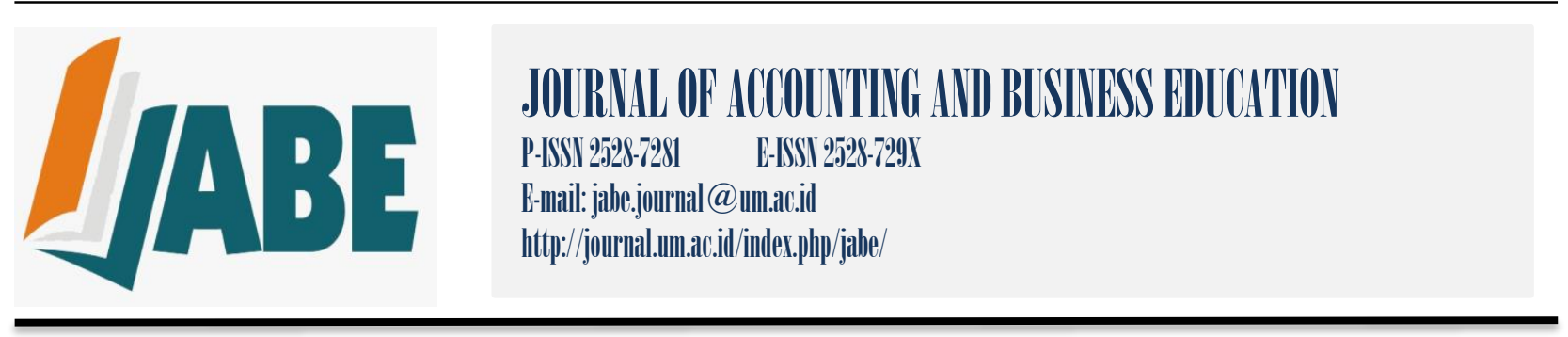

\title{
The Implementation of Self Regulated Learning Model Using Ict Media Toward The Students Achievement in Introduction to Accounting Course
}

\author{
Nyoman Trisna Herawati \\ Universitas Pendidikan Ganesha \\ aris_herawati@yahoo.co.id
}

\begin{abstract}
This study aimed at describing an effect of implementing self regulated learning (SRL) models towards students' achievement in Introduction to Accounting course. The study was conducted at the Department of Accounting in 2015/2016 utilizing a post-test only control group design, involving the second semester students as the subject. The Samples were determined based on simple random sampling in which every individual in the population had an equal chance to be chosen as a sample. The results of the post-test indicated that the students who were treated with self regulated learning (SRL) models had better achievement than those treated with a conventional model. The means score of the experimental group was 79.64 higher than that the control group which was only 69.39. It can be concluded that the students' achievement of experimental group was better than the control group. The result of t-test indicated that the assumption of equal variance not assumed significance probability 2.479 and the significant level about 0.016 (two tail), meaning that significance less than 0.05 . The null hypothesis was rejected and the alternative hypothesis was accepted. This conclude that there was a significant difference between the students' achievement treated by self regulated learning (SRL) models and those treated with conventional models.
\end{abstract}

Keywords: $S R L$, Media ICT, Learning Outcomes

\section{INTRODUCTION}

The quality of Indonesian people as mandated in the vision of national education describes as a people who have skill, spiritual intelligence, emotional, social, and ability to face the global competition and development. Such qualities can be achieved through the provision of qualified education that supported by a qualified learning process as well. The education and learning process should be organized as a lifelong process of culture and empowerment. In the process, educators in this case lecturers should be able to provide and build students' motivation 
to participate actively, and develop the potential, creativity, and independence in learning in accordance with their physical and psychological development. Thus the learning process in college must use innovative learning approach in tranforming the knowledge in both theory and practice. This learning process is implemented to make the learning becomes meaningful through contextual learning principles and student-centered learning.

Basically the most important aims of education are retention and transfer (which indicates a meaningful learning). Retention is the ability to memorize learning materials over a period of time such as the material being taught. Transfer is the ability to apply what has been learned to solve new problems, answer new questions, or simplify new learning materials (Mayer and Winttrok, 1996 in Anderson and Krathwohl, 2010). Learning is not merely recording and memorizing but also experiencing the process. Therefore, learners should be actively encouraged to perform certain activities such as searching and finding their own facts through observation, direct observation, interviews and others. It is very important to be done when the goal of education are not only memorizing or rembering the materials but also applying it in the real life.

Just as learning, teaching is essentially a process. Teaching can be define as the process of organizing the environment to develop and encourage the learners to do some learning activities. Therefore there will be an interactive relation between the educators and the learners to achieve the learning objectives. In this case the role of educators is needed to provide exemplary, develop motivation, potential and creativity of students, so that the goal of learning is not only to pursue the score but also generate students' knowledge and skills.

One of the learning model that support that goal is the independent learning model or the so-called as self-regulated learning (SRL). SRL model emphasizes on skills, processes, and systems rather than content fulfillment and tests. Through the implementation of SRL, students are given autonomy in managing their learning which will lead to the independent learning. Student autonomy in independent learning broadly includes 1) planning, 2) monitoring, and 3) evaluating (Mok \& Lung 2005 in Suardana, 2012). It can be implemented to the learning activities by following several independent learning stages. The first stage is directing the students to analyze their own learning needs, including formulating goals and designing learning programs. The second stage is choosing and implementing learning strategies that are adjusted to the characteristics of students' needs. The third stage is monitoring and evaluating whether the 
strategy has been implemented correctly by checking and reflecting the results obtained from process and product to obtain feedback (Sumarmo.U, 2000).

As the development of infomation communication technology (ICT) in learning the demand on using SRL is increasing.The progress of ICT has facilitate the developers or practitioners to convey information and manage learning activities. One of ICT in learning is an internet media and technology-based media, such as video tutorial, interactive CD, and others. Some of the benefits that can be seen in ICT-based learning are the accessibility of learning resources; it can be accessed anywhere and anytime. The variety of information formats can be delivered in static and dynamic, linear and non-linear with the latest literature. This can lead to high optimism of its ability to improve the effectiveness of learning. Based on the above study, the implementation of SRL model using ICT is appropriate to the spirit of constructivism in learning. The constructivism view in learning requires students to be active, have learning motivation, and have adequate learning independence (Kirna, Sudria and Tegeh, 2015).

The course of Introduction to Accounting 2 introduces and gives an understanding about the concept of the accounting in the balance sheet. This subject demands the conceptual understanding that can be stored in long-term memory to be used as a basis in understanding other financial accounting concepts. However, introducing and understanding new knowledge to the beginners is not easy. Based on the data of previous study, the introduction of accounting score has not reached the minimum mastery standard. In facing the comprehensive exam, almost all students fail because they are unable to answer the concept of financial accounting material. If this problem is not handled properly, then the purpose of Introduction to Accounting course will not be achieved.

Based on the actual conditions there are some problems occur in introduction to accounting course. First is the lack of independent learning. The Learning still uses conventional learning model, in which the lecturers give a lecture or presentation of the material at the beginning of the lecture. Based on the observation, this expository learning model is highly favored by the students and in some case gives satisfactory results. But on the other hand, this model only gives short-term impact to the students. It is limited to the fulfillment of success by having a good score. This indicates that the conventional learning model that begins with a lecture provides only short-term needs without giving the long-term needs. Whereas if the 
students can develop the ability to learn independently, then the learning results will be more qualified, authentic, and imperishable (Suardana, 2012).

Second is the lack of variety in learning resources. The lecturers tend to only use textbooks. In textbooks, there are some explanations of the material followed by comprehension tasks and study cases. This makes the students are not creative in looking for other sources, so students are unable to answer correctly if they are given a task with a little modification or development. Inability to answer the problem correctly is caused by the inability of students in optimizing his cognitive ability and utilizing the existing media. Students' weakness can be seen from the ability to define problem, collect information, memorize, organize, analyze, and evaluate learning process. Based on the problems stated, this study aims to analyze the effectiveness of the implementation of self-regulated learning (SRL) model using ICT toward the students' achievement in Introduction to Accounting course.

\section{LITERATURE REVIEW}

The concept of learning emphasizes on what students know (knowledge) and how they think (cognitive processes) about what they know. Independent learning is required to actualize the meaningful learning. Independent learning can be realized in some freedoms given to students as follows (Rusman, 2010); Students have the opportunity to participate in determining the learning objectives to be achieved in accordance with the conditions and learning needs, students can determine the learning materials on they want to learn and how to learn, Students have the freedom to learn at their own pace, students can determine the evaluation that will be used to assess the progress of learning.

This independence in learning needs to be given to the students so that they have a responsibility in organizing and disciplining themselves and in developing their own learning skills. These attitudes need to be possessed by students, especially adult learners. Independent Learning can be associated with self-regulated learning (SRL). The notion of SRL can be defined as follows (Pintrich and Zusho, 2002 in Nicol and Dick, 2006).

"Self-regulated learning is an active constructive process whereby learners set goals and monitor fr Reviews their learning, regulated, and control Reviews their cognition, motivation, and behavior, guided and constrained by Reviews their goals and the contextual features of the environment" 
Based on the definitions, self-regulated learning aims not only to achieve maximum learning outcomes (cognitive), but also increase student motivation and confidence. The definition also describes the internal characteristics in which the individual directs and focuses on his own learning desires, and takes responsibility for it. The ability of SRL must be owned by every individual, especially those who take higher education. By implementing SRL, lecturers can awaken and empower students as adult learners who should have their own responsibility in learning so that the learning process will be in line with the learning achievement. The better they manage their own learning process the better their understanding of the concepts being studied.

According to Nicol \& Macfarlane, Dick (2006), there are seven principles that can be used in implementing the SRL model. First, helping students to design their own learning activities, start from setting goals, methods, and media to fit the objectives, criteria, and standards expected to be achieved in learning. In this point it is very much emphasized on the goal of learnng or known as learning achievement. Second, facilitating the development of selfassessment (reflection) in learning. Third, providing high quality information to the students about the learning outcomes that have been achieved. Fourth, encouraging student to participate actively in communication among lecturers and fellow students. Fifth, providing positive motivation and foster self-confidence in students. Sixth, giving students the opportunity to understand what has been achieved and what has not been achieved (the gap between achievement and goals). Seventh, providing feedback information to lecturers to improve the quality of the next learning. These seven principles, applied in the syntax of learning that will be used in this study. Some studies show that the SRL model can improve student learning outcomes (Suardana, 2012; Sandyagraha, et al, 2014).

Independent learning requires media that can help students to understand the material. Today ICT is very helpful in the learning process. Research on the utilization of ICT-based learning media shows the improvement of learning quality. ICT-based learning media enables the learning process to achieve "Complex skills" needed in the global era while enabling student centered learning (Mills, 2006). Irwan.F, et al (2014) found that the use of ICT-based learning media is not only beneficial because of its interactivity and accessibility, but also can increase the students' activeness in independent learning. Therefore, the implementation of instructional 
model of SRL assited by ICT is expected to improve student learning outcomes especially in Introductory Accounting course.

\section{METHODS}

Referring to the intended purpose, this research is a quasi experimental research (quasi experiment). In considering that not all variables (symptoms that appear) and experimental conditions can be measured and controlled closely (Dantes, 2012). Experimental design used in this study is the Post-test Only Control Group Design. The subjects of the study are undergraduate students of Accounting Department who take Intensive Accounting course 2 in second semesters. Two classes with equal academic ability are subjected to research. One class is treated as a control group and another class as an experimental group. The control group is a class that is taught by using the direct learning model (conventional) while the experimental group is the class that is learned by using the SRL model. Both classes learn using ICT media, they are on-line learning and interactive CD.Interactive CD provided adapted from inventory accounting learning CDs that have been developed in previous research (Herawati, NT, 2015)

The control group which uses conventional learning is still centered on lecturers, so the role of students to manage their own learning is very limited. The conventional learning syntax sets in this study described as follows. The initial phase provides a lecture contract for a semester at the beginning of the meeting. The lecture contract that is given at least containing the learning achievement (CP) which consists of attitude, knowledge, special skills, general skills, the learning method, the assessment, and the material given at each meeting. The next stage is delivering materials using ICT in the form of a power point, interactive CDs, or downloaded material through the internet. In this case the lecturers explain the media that is used. Then the lecturers asked questions in the form of comprehension or study cases that are done discussed in the class. It can be seen in the syntax of this learning that the role of students is very limited and still waiting for the direction of the lecturer.

In the experimental group, the model of self regulated learning (SRL) that is applied adapt seven basic principles of the SRL model from Nicol and Dick (2006).These seven

principles are described in the following instructional syntax. In general, the syntax in the experimental class begins by giving a lecture contract for one semester (the same as the control class treatment), then the students are directed to design their own learning by agreeing on the 
learning methods and the use ICT that suitable to the characteristics of each student. The learning process is arranged by using group discussion with pre-prepared materials (either via internet, interactive $\mathrm{CD}$, and on-line learning). In this case, the lecturers act as a facilitator. At each end of the meeting, the students are directed to perform a self-assessment (reflection). This can be done by giving a "yes" or "no" assessment questionnaire to each sub-material (indicator) to be achieved in the chapter, including the reasons or points which are not understood. At this point the role of lecturers is very important to provide feedback on the results of self-assessment by students.

Variables in this study include independent variables that are SRL using ICT and the dependent variable that is students' achievement in Introduction to Accounting 2. Student achievement obtained from written test score (UTS value) in the form of case with ideal score is 100. Students achievement will be analyzed using descriptive and inferential statistic, $\mathrm{t}$-test $(t$ test).Descriptive statistical analyzes were used to find mean and standard deviation, whereas inferential statistics were used to test the hypothesis on whether there was a significant mean difference between students who were given ICT-assisted SRL models and conventional models. All statistical test using SPSS 20 for windows with a significant level of $5 \%$.

\section{RESULTS}

The numbers of students involved in this study were 72 people. The students divided into 36 control groups and 36 experimental groups. The mean and standard deviation of the test results in each group can be seen in Table 1 as follows.

Table 1. Average Score and Standard Deviation of learning outcome in Control and Experimental Group

\begin{tabular}{|c|c|c|c|c|c|c|}
\hline & Learning Models & $\mathrm{N}$ & Mean & Std. Deviation & $\begin{array}{l}\text { Std. } \\
\text { Mean }\end{array}$ & Error \\
\hline Learning & Control Group & 36 & 69.39 & 19.861 & 3.310 & \\
\hline outcome & Experimental Group & 36 & 79.64 & 14.873 & 2.479 & \\
\hline
\end{tabular}

In general, students' achievement in experimental group is better than controls group. The results of the data showed that the experimental group had a higher average that was 79.64> 69.39 and lower standard deviation that was $14.87<19.86$ than the control group. This indicates that the level of heterogeneity between groups is relatively not much 
different. Absolutely, the average of accounting learning outcomes is different between the control group and experimental group. To see if this difference is statistically significant then hypothesis testing using t-test was used. The alternative hypothesis (Ha) is "there is a significant difference between the Introductory Accounting learning outcome of students who were taught by the ICT-assisted SRL model and the students who were taught by the conventional model ". Hypothesis testing through t-test for independent samples can be seen from Table 2 below.

Tabel 2 The results of t-test

\begin{tabular}{|c|c|c|c|}
\hline \multirow{4}{*}{$\begin{array}{l}\text { Levene's Test for } \\
\text { Equality of Variances }\end{array}$} & \multirow[b]{3}{*}{$\mathrm{F}$} & \multicolumn{2}{|c|}{ Learning Outcome } \\
\hline & & $\begin{array}{l}\text { Equal } \\
\text { variances } \\
\text { assumed }\end{array}$ & Equal variances not assumed \\
\hline & & 4.869 & \\
\hline & Sig. & .031 & \\
\hline \multirow{7}{*}{$\begin{array}{l}\text { t-test for Equality of } \\
\text { Means }\end{array}$} & $\mathrm{T}$ & -2.479 & -2.479 \\
\hline & Df & 70 & 64.863 \\
\hline & Sig. (2-tailed) & .016 & .016 \\
\hline & Mean Difference & -10.250 & -10.250 \\
\hline & Std. Error Difference & 4.135 & 4.135 \\
\hline & 95\% Confidence Lower & -18.498 & -18.509 \\
\hline & $\begin{array}{l}\text { Interval of the Upper } \\
\text { Difference }\end{array}$ & -2.002 & -1.991 \\
\hline
\end{tabular}

From Table 2 above, we can analyze two things. First is testing whether the population variance is equal or not, it can be seen from the Levene Test. After knowing whether the variance is equal or not, step two is to see the value of $t$-test to determine whether the differences in average are significant or not (Ghozali, Priest, 2012: 67). The test results show the value of F count Levene's Test is 4869 with a probability of $0.031<0.05$, it can be concluded that populations have different variances. Thus the t-test should be based on the assumption of equal variance not assumed. From SPSS output, it shows that the value of $t$ on the assumption of equal variance not assumed is 2.479 with significant probability is 0.016 (two tail). This significance is less than 0.05 , so the results of this test indicate that there is a difference in mean value of learning outcomes between the experimental group and the control group. Basedere was a significant effect $(<0.05)$ on the imlementtion of self regulated learning to the students' achievement. 


\section{DISCUSSION}

Introduction to Accounting 2 focuses on learning accounting on items in the balance sheet including cash accounting, accounts receivable, inventory, fixed assets, current debt, bonds, and equity. The density of material in this course makes direct learning is difficult to be done. The activities of lecturers outside teaching hours (Tri Dharma activities) and nonscheduled holidays make learning are not fully implemented. If this is the case for a transport driver, a sudden stop is inevitable (Setiawan, Kamayanti, and Mulawarman 2014). In other word, the first weeks of meetings are still work well in accordance with the rules, 2.5 hours for 3 credits. However, usually at the end of the meetings where the final exam is scheduled, there some materials that are not delivered yet, so the thing that possibly done by lecturers is adding some hours which is not 2.5 hours full. This problem requires lecturers to use innovative learning models that can help to mediate the gap between teaching time and the quality of learning. In addition, the utilization of ICT media is also very necessary to provide insight and flexibility to students to access information anywhere and anytime.

Currently, the learning of accounting has used many ICT media such as electronic learning media (e-book, e-module), interactive $\mathrm{CD}$, internet, and other media. But this medium is often combined with direct or conventional learning that is usually using lectures and discussions. Lecturers provide materials in the form of media, then students look at it and discuss in groups. Sometimes the lecturers explain the existing material in the ICT media. It can be observed that the learning of accounting by using ICT media has been done, but its application in the learning model is still using conventional model. This indicates less than satisfactory learning outcomes. For the purpose of this study was to analyze the effectiveness of self-learning models (self-regulated learning) media aided ICT to improve learning outcomes Introduction to Accounting 2.

Based on the research results, it proves that the use of self regulated learning effects the student learning outcomes. It is roven from the difference in student learning outcomes between the experimental group and control group $($ sig. $=0.016<0.05)$. The learning outcomes of the group that using SRL model (experimental group) was better than control group that use conventional learning. This can be seen from the average value in the experimental group, 79.64 are higher than the control group, 69.39 . 
The average score in both the experimental group and control group are good with average ranges from 69-79. This proves that the use of ICT media helps students in understanding the concepts of financial accounting, for example on the bank reconciliation topic. In this case, the student can be directed to look for sample bank accounts on the internet, then analyze the transaction mutations in the current account and match them with cash mutations in the company journal as raw material in the preparation of the bank reconciliation report. In addition, students can also be directed to understand how to prepare bank reconsilation reports through internet media. According to Edgar Dale in (Sanjaya, 2008), the role of the media in the process of gaining learning experiences is very important. It shows the more concrete the students learn the teaching materials, through direct experience, the more experience the students get. Conversely the more abstract the students gain experience, relying only on verbal language, the less experience students will gain. This can be seen from the percentage of students' ability to remember only $10 \%$ of what is read, $20 \%$ of what is heard, $30 \%$ of what is seen, $50 \%$ of what is heard and seen, and $70 \%$ of what is done. So it can be seen that the use of audio visual media is better to provide learning experience.

Good learning illustrates the efforts of educators to make the learners have their own responsibility. This means that learning activities are meaningless if they do not produce learning activities for their students. Learning activities will only work if the learners are actively experiencing their own learning process. Thus the role of teachers / lecturers is to make every student interact actively with various sources of learning or media that exist. The media in the learning process have a very important position, because it is able to bridge the messager and the recipient of the message. Media helps students gain experience by using the time and activities directed, so that the learning outcome obtained is better and able to minimize the miss conception by students (Sanjaya, 2008).

On the other hand, media utilization should also be collaborated with appropriate learning models. Conventional learning models uses the media is considered less effective. That is why in this study the researcher uses self regulated learning to improve students' passion in learning. Self-Regulated Learning model is a model of student-centered learning (student centered). The lecturers act as a facilitator by providing positive feedback to the students. Feedback can be given by friends or lecturers themselves through several ways, among others: discussing with the group to overcome the points of material that have not mastered, 
lecturers providing direction, encouragement, and motivation so that they are able to solve existing problems. In the model of self regulated learning the students are given a chance to find their own teaching methods, how to effectively use ICT media, and doing self assesment. Selfassessment can be done through case studies or quizes then assessed by the students themselves. The lecturers' role is to provide feedback on the quiz results (in the form of scores) and the results of the self-assessment questionnaires (from "yes" and "no" answers). In this case, lecturers can focus more on feedback for students whose test scores are still low. Selfassessment (reflection) is essential to foster confidence in students. The students will be able to put themselves in the material that is already understood and has not yet understood. Based on this self-assessment the studens can improve their performance in completing the task, thus impacting on the improvement of their learning achievement (McDonal \& Bound in Nicol \& Dick, 2006).

The results obtained in this study indicate that the implementation of self regulated learning models requires students to manage learning resources that exist in accordance with the needs of the learning context. These findings are consistent with research (Suardana, 2012), which states that the imlementation of self regulated learning models can increase activity, results, and independent learning. The improvement of the learning indicates that students are working hard to be able to solve the problems encountered. If students have difficulty in solving the problem, they can ask their friends or lecturers. This condition allows students to develop independent learning that includes planning, monitoring, and evaluating which has implications for the improvement of student learning outcomes. This is consistent with the finding (Sanyagraha, Dantes, and Widiartini, 2014) which states that there are significant difference between the students achievement of Civics lesson in Accounting Vocational High School that using self regulated learning based on performance assesment and the students that using conventional model. The students' achievement of civic lesson that uses self regulated learning is better than the students achievement that using conventional model.

Self regulated learning model is a learning process that is carried out on the initiative of individual. In this case the planning, implementation, and assessment of learning experience is done by the learners. The role of the lecturer is as a consultant, giving direction, guidance, and confirmation on the progress of learning undertaken by learners with the goal of empowering the ability of learners. According to Dantes (2011), the responsibility of the lecturers not only to 
enhance cognitive abilities (instructional effect) but also enhance the values of humanity (nurturant effect). It is further mentioned that a professional lecturer is a lecturers that are capable of animating and transfroming various values of life both hard skills and soft skill so on the life and the growth of the life. Thus, the main task of educators is not merely achieving the learning objectives but also increasing student independence in learning. Self regulated learning can also improve verbal communication among students. Although the way of thinking and working in completing the task follow certain rules, but it can vary according to the problems encountered and the standpoint of learners in solving the problems. The variety of viewpoints will foster the various way of thinking and working that will also foster the creativity of students (Nitiasih, et al, 2001). In addition, self regulated learning model is useful to resuscite and empower learners that learning is their own responsibility. Given the freedom to students in the learning process awaken their responsibility towards all the thoughts and behaviors that have an impact on increasing independence in learning.

\section{CONCLUSION}

Based on data analysis, it can be concluded that students taught with SRL using ICT have better learning outcomes than the students taught with conventional models. This can be demonstrated by the average value of the experimental group is higher than the average of the control group (79.64> 69.39) with a figure of significance in t-test is less than 0.05, which shows the average difference was significant. It shows that SRL models success due to several factors. First, the role of ICT media greatly affects the implementation of SRL. ICT is helping students to make the learning process become better. Second is the lecturers act as a facilitator. During this time the role of the lecturer is still heavily involved in the provision of material through lectures. The lecture method is no longer able to provide maximum results especially in foster creativity and learning motivation of students. With the SRL models, students are taught to learn independently, from designing learning methods up to conducting self assessments. This selfassessment is very important for students to know which material has been understood and materials which are not yet understood. Through the feedback given the lecturer, the material that are not yet understood can be discussed with peers and lecturer itself. By having selflearning, students will be able to understand the concept in more depth, and is also beneficial to 
empower the resonsibilty. In other words, learners are encouraged to be responsible for all the thoughts and actions to increase the independence in learning.

Some suggestions in this study are as follows. First, SRL models can be implemented in introduction to accounting course. It is mainly to increase the independence of learning to achieve maximum learning outcome. Second, the role of the lecturer is very important as a facilitator of learning. Time limitation in learning can be overcome by designing more effective classroom management. Besides, the use of ICT can motivate students to learn actively in solving the problem in accordance with the learning objectives that have been set. This study applied to students who sit at the initial level (second semesters), so there are chances of them carried on teaching model in high school. It can be seen,at the beginning of the meeting the students have not been able to explore independently and does not have the confidence to solve a problem. For the future, SRL models can be applied to further semester students with financial accounting course.

\section{REFERENCES}

Anderson,W.Lorin dan Krathwohl,R David. 2010. Kerangka Landasan Untuk Pembelajaran, Pengajaran, dan Asesmen (Revisi Taksonomi Pendidikan Bloom). Terjemahan oleh Prihantoro, Agung. dengan Judul Asli A Taxonomy for Learning, Teaching, and Assesing: A Revision of Bloom's Taxonomy of Educational Objectives.Yogyakarta:Pustaka Pelajar

Dantes, Nyoman.2012. Metode Penelitian. Yogyakarta: Penerbit Andi

. 2011. Penyusunan Struktur Kurikulum Program Studi Diploma dan Strata 1 di Lingkungan Universitas Pendidikan Ganesha, Makalah, Disajikan dalam Lokakarya Kurikulum Undiksha 5 Desember 2011

Herawati,N.T.2015. Pengembangan Perangkat Pembelajaran Akuntansi Dengan Model Concept Attainment Berbasis CD Interaktif. Proseding Seminar Nasional Riset Inovatif (SENARI) Ke-3 lembaga Penelitian Undiksha, Kuta-Bali 18-19 Nopember 2015

Kirna, Sudria, dan Tegeh. 2015. Apa Respons dan Harapan Siswa SMA Tentang Blended Learning. Jurnal Pendidikan dan Pengajaran (JPP),48(1-3):15-26

Mills, C Steven. 2006. Using the Internet for Active Teaching and Learning. Ohio: Pearson Merrill Prentice Hall

Irwan. F, I W. Santyasa, I M. Tegeh,Pengembangan Multimedia Interaktif Berbasis Self Regulated Learning Dengan Moel ADDIE Untuk Meningkatkan Prestasi Belajar Seni 
Budaya Bagi Siswa Kelas VII SMN Negeri 3 Mendoyo, ejournal PPS Undiksha Program Studi Teknologi Pendidikan. Volume 4 tahun 2014.online.http://pasca.undiksha.ac.id/e-journal/index.php/jurnal_ep/article /view/1142, diakses tanggal 10 Oktober 2016

Nicol,J David \&Dick,Macfarlane Debra.2006.Formative Assesment and Self-Regulated Learning: a Model and Seven Pronciples of Good Feedback Practice. Studies in Higher Education,31(2):199-218.Online.htpp://dx.doi.org/10.1080/03075070600 57290,diakses tanggal 17 September 2016

Nitiasih,dkk.2001. Pengembangan Model Pembelajaran dengan "Self Directed Learning" dalam Program Intensive Course sebagai Upaya Meningkatkan Kemampuan Komunikasi Verbal Mahasiswa Program Studi Pendidikan Bahasa Inggris. Laporan Penelitian. Tidak Diterbitkan. Singaraja: STKIP

Sandyagraha, Dantes, dan Widiartini.2014.Pengaruh Penerapan Model Self Regulated Learning Berbasis Asesmen Kinerja Terhadap Prestasi Belajar PKn dengan Kovariabel Self Efficacy Pada Mahasiswa Kelas IX Jurusan Akuntansi SMKN 1 Singaraja. ejournal PPS Undiksha Program Studi Evaluasi Pendidikan. Volume 4 tahun 2014.online.http://pasca.undiksha.ac.id/e-journal/index.php/jurnal_ep/article /view/1142, diakses tanggal 10 Oktober 2016

Sanjaya, W. 2008. Perencanaan dan Desain Sistem Pembelajaran. Jakarta: Kencana Prenada Media Grup

Setiawan, Kamayanti, Mulawarman.2014. Pengakuan Dosa $[\operatorname{Sopir}] \mathrm{A}[\mathrm{Ng}] \mathrm{Ku}[\mathrm{N}]^{\mathrm{T}}$ an Pendidik:Studi Solipsismish. Jurnal Pendidikan Akuntansi (JPA), 2(1):5-14

Suardana, I Kade.2012. Implementasi Model Belajar Mandiri untuk Meningkatkan Aktifitas, Hasil, dan Kemandirian Belajar Mahasiswa. Jurnal Pendidikan dan Pengajaran $(J P P), 45(1): 56-65$

Sumarmo, U.2000. Kemandirian belajar: apa, mengapa, dan bagaimana dikembangkan pada peserta didik. Makalah disajikan pada Seminar Pendidikan Matematika di Jurusan Pendidikan Matematika FMIPA Universitas Negeri Yogyakarta,(Vol. 8).online. https://scholar.google.co.id/scholar?q=related:xn5tNo3jllYJ :scholar. google.com /\&hl=id\&as_sdt=0,5\&as_vis=1, diakses tanggal 10 November 2016 